Nazhruna: Jurnal Pendidikan Islam

Vol. 4 No 1, 2021. pp. 1-17 E-ISSN: 2614-8013

DOI: https://doi.org/10.31538/nzh.v4i1.1022

\title{
UNIVERSITY STUDENTS' PERCEPTION ON THE IMPLEMENTATION OF ONLINE LEARNING DURING THE COVID-19
}

\author{
M Nurul Ikhsan Saleh ${ }^{1}$, Ratna Sari ${ }^{2}$, Puji Alim ${ }^{3}$ \\ Universitas Islam Indonesia, Indonesia ${ }^{1}$ \\ Universitas Muhammadiyah Yogyakarta, Indonesia ${ }^{2}$ \\ Goethe University Frankfurt, Germany ${ }^{3}$ \\ mnurul.ikhsan.saleh@uii.ac.id, ratna.sari@umy.ac.id, S5252091@stud.uni-frankfurt.de
}

Received: 18-10-2020 Revised: 03-12-2020 Accepted: 15-01-2021

\begin{abstract}
The spread of the Coronavirus disease (COVID-19) pandemic in many countries around the world has changed the learning-teaching process in higher education sectors from face-to-face learning to online learning. This study aims to understand undergraduate students' views on the implementation of online learning during the COVID-19 pandemic. This research was conducted on 4th to 8th-semester students at the Islamic higher education, Universitas Islam Indonesia, using a qualitative case study. Findings of the study have consisted of three broad themes; firstly, the advantages of online learning: increasing technological literacy, flexibility in learning, improving selfability, being financially efficient, and supported various learning media; secondly, the weaknesses of online learning: heavy tasks, less effective and decreased enthusiasm, little control from the lecturers, and technical problems; thirdly, constructive feedback on the implementation of online learning: the creation of interesting learning videos, fun learning strategies, holding quizzes, notification of lectures to be multiplied, free internet quota, and additional time for working on assignments. The findings reinforce other studies where the implementation of online learning still requires improvements, particularly during the COVID-19 pandemic. This research can be a reference in policymaking. Further research is needed from the perspectives of lecturers and policymakers to complement the findings.
\end{abstract}

Keywords: COVID-19 Pandemic, Online Learning, University students.

\section{Abstrak}

Penyebaran pandemi penyakit Coronavirus (COVID-19) di banyak negara di dunia telah mengubah proses pembelajaran di sektor pendidikan tinggi dari pembelajaran tatap muka menjadi pembelajaran online. Penelitian ini bertujuan untuk memahami pandangan mahasiswa perguruan tinggi tentang pelaksanaan pembelajaran online selama pandemi COVID-19. Penelitian ini dilakukan pada mahasiswa semester 4 sampai 8 di perguruan tinggi Islam, Universitas Islam Indonesia, dengan menggunakan penelitian kualitatif jenis studi kasus. Hasil penelitian terdiri dari tiga tema besar; pertama, keunggulan pembelajaran online: meningkatkan literasi teknologi, fleksibilitas dalam belajar, meningkatkan kemandirian, bemat secara finansial, dan didukung berbagai media pembelajaran; kedua, kelemahan pembelajaran online: tugas berat, kurang efektif dan semangat menurun, kontrol dosen kurang, dan kendala teknis; ketiga, tanggapan konstruktif atas pelaksanaan pembelajaran online: pembuatan video pembelajaran yang menarik, strategi pembelajaran yang menyenangkan, diadakannya kuis, notifikasi kegiatan perkuliahan diperbanyak, kuota internet gratis, dan tambahan 
waktu mengerjakan tugas. Temuan tersebut menguatkan penelitian lain dimana implementasi pembelajaran online masib perlu perbaikan, terutama selama pandemi COVID-19. Penelitian ini dapat menjadi acuan dalam pembuatan kebijakan. Diperlukan penelitian lebih lanjut dari perspektif dosen dan pembuat kebijakan untuk melengkapi temuan penelitian ini.

Kata Kunci: Pandemi COVID-19, Pembelajaran Online, Mahasiswa Pendidikan Tinggi.

\section{INTRODUCTION}

During the COVID-19 pandemic, the use of online learning in the teaching and learning process at universities increased sharply in the world, especially in Indonesia. With a total of 4,670 universities and 8,043,480 students enrolled in Indonesia, ${ }^{1}$ the Minister of Education and Culture instructed the use of online learning for all tertiary institutions in Indonesia through Circular No.36952 during the COVID-19 pandemic. $^{2}$ The majority of educational institutions in the world also stop learning and teaching that requires face-to-face learning to suppress the transmission of the COVID-19 pandemic and to maintain student safety. ${ }^{3}$ The Government of Indonesia urges the public at large to conduct social distancing to avoid interpersonal physical contact in public places, including within the university. The social distancing method is to reduce the spread of the 2019 novel coronavirus in the community because it is believed to occur through human-to-human transmission which was originally spread in China. ${ }^{4}$ The spread of the COVID-19 has affected not only the learning process but also how the management of tertiary institutions, organizations, and community interactions. ${ }^{5}$ The enactment of online learning due to an emergency spreading of the virus is not the first time since this has happened in 2020. In 2009, the same thing happened when the spread of H1N1 pandemic flu caused several educational institutions to organize online teaching. ${ }^{6}$

Online learning is considered the best choice to allow learning to continue during the COVID-19 pandemic even though this choice was made in an emergency and unexpected circumstances. The hospital which is dealing directly with the handling of people affected by the COVID-19 also appreciates the steps of the university to stop learning that requires faceto-face learning to reduce transmission of the virus. Then the government policy was issued through the minister of education who called for the use of online learning both at universities or other educational institutions called Work from Home (WFH) or study from home. The ideal form of learning after the COVID-19 pandemic is still in question, where interactions are certainly not as flexible as before the pandemic. It is possible that students still wear masks or still maintain social distancing. The real phenomenon is an increase in usage in

\footnotetext{
1 Pusdatin Kemenristekdikti, "Statistik Pendidikan Tinggi 2018," Jakarta: Pusdatin Iptek Dikti, Setjen, Kemenristekdikti, 2018.

${ }^{2}$ Kementerian Pendidikan dan Kebudayaan, "Surat Edaran Menteri Pendidikan Dan Kebudayaan Republik Indonesia Nomor 36962," 2020.

3 UNESCO, "Education: From Disruption to Recovery," 2020, https://en.unesco.org/covid19/educationresponse.

${ }^{4}$ Yan Bai et al., "Presumed Asymptomatic Carrier Transmission of COVID-19," Jama 323, no. 14 (2020): 1406-7.

${ }^{5}$ Michael P A Murphy, "COVID-19 and Emergency ELearning: Consequences of the Securitization of Higher Education for Post-Pandemic Pedagogy," Contemporary Security Policy, 2020, 1-14. 2010).

${ }^{6}$ I Elaine Allen and Jeff Seaman, Learning on Demand: Online Education in the United States, 2009. (ERIC,
} 
the world of education related to video conferencing tools, online learning software, virtual tutoring, and language apps. ${ }^{7}$

One of the challenges faced by universities during the COVID-19 pandemic is how to ensure the quality of online teaching-learning is not different from the quality of the face-toface learning process. Universities have been competing to find the best formula for online learning since there is no standard given yet by the government, especially in Indonesia. It is very important to ensure quality online learning in which the design is no longer due to an emergency, but also how the strategy used is applicable if the second wave of COVID-19 appears or similar viruses attack in the future. The readiness of the universities to carry out online learning in any situation becomes an obligation. Currently, universities have to prepare lecturers with good information and technology to be able to carry out online learning. A study of several universities in the 20th century during the COVID-19 pandemic showed that it is important for universities to share and learn from each other in the development of teaching and learning. ${ }^{8}$

Several studies show successes from universities in implementing online learning. For example, one study was conducted among English students showed that with the availability of internet, online learning helps the teaching-learning process during COVID-19. Furthermore, online learning helps students to maintain physical distance to avoid the spread of the virus. On the flip side, the study finds out that students need more explanation on the learning material and clear instruction on the assignment given. To overcome the problem, it suggests the use of voice recording available by free messenger application to help students with their understanding. ${ }^{9}$

Despite the successes, several studies reveal weaknesses of online learning during COVID-19 pandemic. One study shows that the application of online learning has flaws in teachers' attendance and reduced the importance of social relations. The negative impacts created are decreasing enthusiasm in learning among students that might lead to more fatal impact of dropping out from class. Furthermore, online leaning causes difficulties for lecturers to enforce the students' presence in the learning process. Bower and Kumar's research on students' perception of online and face-to-face learning, on the other hand, finds out that teachers are more presence in online than traditional face to face classes. ${ }^{10}$

Other important studies related to success and weakness in online learning to note are from Lederma ${ }^{11}$ and Bao. ${ }^{12}$ Lederman, quoting Flower Darby, a teaching director at Northern

\footnotetext{
${ }^{7}$ Cathy Li and Farah Lalani, "The COVID-19 Pandemic Has Changed Education Forever. This Is How," World Economic Forum, 2020, https://www.weforum.org/agenda/2020/04/coronavirus-education-globalcovid19-online-digital-learning/.

8 Joseph Crawford et al., "COVID-19: 20 Countries' Higher Education Intra-Period Digital Pedagogy Responses," Journal of Applied Teaching and Learning (JALT) 3, no. 1 (2020).

${ }^{9}$ Markus Deli Girik Allo, "Is the Online Learning Good in the Midst of Covid-19 Pandemic? The Case of EFL Learners,” Jurnal Sinestesia 10, no. 1 (2020): 1-10.

10 James Bowers and Poonam Kumar, "Students' Perceptions of Teaching and Social Presence: A Comparative Analysis of Face-to-Face and Online Learning Environments," International Journal of Web-Based Learning and Teaching Technologies (IJWLTT) 10, no. 1 (2015): 27-44.

11 Doug Lederman, "Preparing for a Fall Without In-Person Classes," Inside Higher Ed, 2020, https://www.insidehighered.com/digital-learning/article/2020/04/01/preparing-quietly-fall-semester-withoutperson-instruction.
} 
Arizona University, stated that teaching instruction in most college is not very good even in fact most professors are aware of this. Bao in his research found out that educators at Peking University still face a lack of experience in online learning when they have to teach fully online during the COVID-19 Pandemic.

From some of the literature and research conducted previously, researchers conclude that there is still a gap in studies that focus on the perceptions of undergraduate students in higher education, especially at Universitas Islam Indonesia implementing online learning during the Covid-19 Pandemic. The novelty of this research is that it not only examines the advantages and disadvantages of implementing online learning during the Covid-19 pandemic, but also the researchers investigate the feedback which hopefully can help stakeholders in universities or policymakers in Indonesia to improve the implementation of the learning and teaching process.

\section{METHOD}

From previous studies, there is still no research in private Islamic tertiary institutions in Indonesia that comprehensively examines the application of online learning during the COVID-19 Pandemic. This study specifically examines undergraduate student's views regarding the implementation of online learning at Universitas Islam Indonesia (Universitas Islam Indonesia). Students were asked about the application of online learning and their feedbacks on improving the implementation of online learning in a tertiary institution during the COVID-19 pandemic. This research uses a case study qualitative method. Researchers use interviews in collecting data. Interviews were conducted for undergraduate students in 4 th to 8th-semester with main reason that students from those semesters have experienced face-toface learning (blended learning) and learning through Google Classroom. Participants of the interview consisted of 36 undergraduate students. The names of the participants were anonymous in the study. The data analysis technique used is Miles, Huberman, and Saldana's methods, which is an attractive analysis that includes: data condensation, data display, and conclusion drawing or verification. ${ }^{13}$ From the results of the interviews, a thematic analysis was carried out to formulate important themes found in this study.

This research was conducted at Universitas Islam Indonesia because it became one of the private Islamic tertiary institutions which quickly implemented online learning through the rector's decision Number 1048/Rek/10/SP/III/2020 in response to the spread of COVID19. Online teaching and learning processes are common for the majority of lecturers at Universitas Islam Indonesia utilizing Google Classroom. Especially with the COVID-19 pandemic, all teaching and learning process runs completely online. Through the rector's decision during the COVID-19 Pandemic period this was not only the learning process in the classroom that was changed to online but also administrative matters within UII. Furthermore, the university limits national and international mobility, and even mobilization is arguably not permitted for activities that require overseas travel and arrival of people from abroad to campus. The decision was issued in March 2020 and the following three decisions

12 Wei Bao, "COVID-19 and Online Teaching in Higher Education: A Case Study of Peking University," Human Behavior and Emerging Technologies 2, no. 2 (2020): 113-15.

13 A Michael Huberman, Mathew Miles, and Johnny Saldana, "Qualitative Data Analysis: A Methods Sourcebook," The United States of America: SAGE Publications, 2014. 
were reissued, which finally eliminated face to face learning until the end of the semester, July 2020. All staff at UII worked from home. End of semester exams, presentation of thesis, and graduation final assignments are held online.

\section{RESULTS AND DISCUSSION}

In general, Universitas Islam Indonesia has implemented a combination of synchronous and asynchronous learning activities. Lecturers are given the freedom to choose the use of learning media in the teaching and learning process. Universitas Islam Indonesia provides several teaching and learning process applications, such as subscribing to the Zoom application for synchronous learning activities and subscribing to the Panopto application for asynchronous learning activities, and the Google Classroom learning media application as a minimum standard for using online learning media. ${ }^{14}$ Choosing synchronous or asynchronous learning activities certainly has its advantages. One study revealed that synchronous activities could increase the involvement, understanding, and performance of students with disabilities, ${ }^{15}$ and other research shows the advantages of asynchronous learning activities which are flexible and easy. ${ }^{16}$ In the results and discussion sections of this research, the researchers divide the results into three major sub-themes, namely the advantages of online learning, the weaknesses of online learning, and constructive feedback on the implementation of online learning.

\section{The Advantages of Online Learning}

Online learning has been using massively during the COVID-19 pandemic in schools or universities in many countries. There are around 186 countries that close schools due to the COVID-19 pandemic. $^{17}$ The COVID-19 pandemic spreads rapidly in this world where more than 100,000 cases every day in the world have infected more than 6 million people and caused more than 380,000 deaths from the last data of June $2020 .{ }^{18}$ Inevitably almost all universities in the world run the process of teaching and learning online. Online learning is interpreted as a teaching-learning activity that is at least 80 percent conducted online, which at least 30 percent consists of instructions and the remaining material is online teaching material. ${ }^{19}$ Initially, before the COVID-19 pandemic, many of the universities did not apply full online learning, but many of them carried out blended learning in which learning was based on face-to-face meetings in class with additional online learning. The application of blended learning helps to improve the quality of face-to-face teaching by presenting learning content through the use of online learning-based technology and teaching and learning in the

\footnotetext{
14 Universitas Islam Indonesia, "Panduan Perkuliahan Daring Universitas Islam Indonesia" (Yogyakarta, 2020), https://docs.google.com/document/u/1/d/e/2PACX1vQpfkxDJ8q50jWupY1qzvWcx88VkmX82nPvJDPHC5EvIUFRZiUX1ziQTdfvhho45MGAUr2E1YrsjNG/pub.

15 Ibrahim Dahlstrom-Hakki, Zachary Alstad, and Manju Banerjee, "Comparing Synchronous and Asynchronous Online Discussions for Students with Disabilities: The Impact of Social Presence," Computers \& Education 150 (2020): 103842.

${ }^{16}$ Mehmet Gazan, "Synchronous and Asynchronous Online Learning: Perceptions of Students at a State University in Turkey," FIRE: Futuristic Implementations of Research in Education 1, no. 2 (2020): 96-107.

${ }^{17} \mathrm{Li}$ and Lalani, "The COVID-19 Pandemic Has Changed Education Forever. This Is How."

${ }_{18}$ The New York Times, "Coronavirus Live Updates: The Number of Cases Is Growing Faster Than Ever Worldwide," The New York Times, 2020.

${ }^{19}$ Allen and Seaman, Learning on Demand: Online Education in the United States, 2009.
} 
classroom is focused on improving the skills of each individual after learning the content of lessons online. ${ }^{20}$ At the time of the COVID-19 pandemic, the majority of universities are implementing full online learning in which according to the perception of undergraduate students gave advantages in the teaching and learning process. In the successful implementation of online learning, Universitas Islam Indonesia provides several learning applications such as Google Classroom, Zoom, and Panopto, but lecturers are advised to combine them in teaching because each learning application has different advantages features. ${ }^{21}$ This approach is in line with directions from the Ministry of Education and Culture of the Republic of Indonesia in avoiding on-site interactions in the teaching and learning process in Higher Education. ${ }^{22}$

\section{Increasing Technological Literacy}

Four advantages of online learning in Holmes and Gardner's research are increasing students' knowledge in using technology, adding to the learning experience of students, enriching students' methods of learning, expanding changes in learning theory. ${ }^{23}$ The results of interviews in this study are found to be in line with the results of Holmes and Gardner's research that the application of online learning in the COVID-19 Pandemic period could improve students and lecturers in the use of technology. Students considered becoming more tech-savvy by becoming increasingly accustomed to using online learning during the COVID19 pandemic. Some lecturers are even known to have used online learning media like Google Classroom, whereas previously during regular lectures in class they did not implement online learning. The following is what the undergraduate students have said.

The advantages of online learning for me is that I can learn and I can learn technology, especially learning with internet media. ${ }^{24}$

The advantage of online learning is that I am studying more and more the online system..$^{25}$

I am more able to divide my time not to spend time playing cell phone that is not important and I use social media wisely. ${ }^{26}$

Before the COVID pandemic 19, there were still several lecturers who did not use Google Classroom, but now all lecturers can operate Google Classroom or other learning media for online learning. ${ }^{27}$

\section{Flexibility in Learning}

Online learning is a hope where education runs well without physical, social, and geographical gaps. Learning is not limited by location and time, where students are free to choose where they want to study and anytime. Online learning is idealized as a medium for

\footnotetext{
${ }^{20}$ José Antonio Bowen, Teaching Naked: How Moving Technology out of Your College Classroom Will Improve Student Learning (John Wiley \& Sons, 2012).

${ }^{21}$ Universitas Islam Indonesia, "Panduan Perkuliahan Daring Universitas Islam Indonesia."

22 Kemdikbud RI, "Panduan Penyelenggaraan Pembelajaran Semester Gasal 2020/2021 Di Perguruan Tinggi” (Jakarta, 2020), https://dikti.kemdikbud.go.id/wp-content/uploads/2020/06/PanduanPenyelenggaraan-Semester-Gasal-2020-2021-di-PT.pdf.

23 Bryn Holmes and John Gardner, E-Learning: Concepts and Practice (Sage, 2006).

24 Aqmar, "6th-Semester Male University Student, Interview, 9 May," 2020.

25 Nadhif, "4th-Semester Male University Student, Interview, 10 May,” 2020.

26 Afira, "6th-Semester Female University Student, Interview, 10 May," 2020.

27 Afiya, “6th-Semester Female University Student, Interview, 15 May,” 2020.
} 
learners to get information, evaluate information, collaborate with other friends, and then be able to transform it into knowledge for the development of each individual. However, the biggest challenge is how to ensure flexibility in online learning goes as expected where the teaching and learning process is not merely focused on pursuing certain standards that can be applied in conventional learning, rather than on developing constructive learning models and individual development. ${ }^{28}$ In this study, students stated that the application of online learning makes the teaching and learning process flexible, learning anywhere, accessing material at any time. Furthermore, students can learn while doing other things and if students do not understand some of the explanations in the course material, they only need to repeat reading the course material that has been posted by the lecturer. The following are what four undergraduate students have testified.

This online learning has the advantage of being accessible anywhere with a good internet network condition and of course, the presentation of the material is far more creative. ${ }^{29}$

Online learning is flexible because courses can be learned via YouTube or PowerPoint. The course can also be studied anywhere, anytime, while doing anything as long as connected to the internet. ${ }^{30}$

Besides the focus of online learning, I sometimes intersperse with other useful things, and I still go through the course with full awareness. ${ }^{31}$

The material provided can be played back so that I can do the exercises at another time by looking at the current conditions with my unpredictable busyness because I help my family's work in making money. 32

\section{Improving Self-Ability}

Undergraduate students consider that by applying online learning during the COVID-19 pandemic, they can improve their abilities, such as independence, activeness, creativity, responsibility, and becoming a greater student. Another study also found that online learning has empowered students with digital fluency. ${ }^{33}$ Furthermore, one participant also revealed that the use of online learning can improve skills that can be applied later when possibly virus spreads in the future when they become teachers. The following are the university students' perspectives.

The advantage of online learning is that it makes undergraduate students accustomed to independent learning from all aspects: understanding lecturer explanations, and doing quizzes. Undergraduate students are also required to read a lot and be able to analyse a problem. ${ }^{34}$

${ }^{28}$ Holmes and Gardner, E-Learning: Concepts and Practice.

${ }^{29}$ Aiza, "6th-Semester Female University Student, Interview, 9 May," 2020.

30 Barika, "4th-Semester Female University Student, Interview, 9 May,” 2020.

${ }^{31}$ Bashirah, "4th-Semester Female University Student, Interview, 9 May," 2020.

32 Bushra, "4th-Semester Female University Student, Interview, 9 May," 2020.

33 Tatiana Tchoubar, Thomas R Sexton, and Lori L Scarlatos, "Role of Digital Fluency and Spatial Ability in Student Experience of Online Learning Environments," in Science and Information Conference (Springer, 2018), 251-64.

${ }^{34}$ Dalilah, “4th-Semester Female University Student, Interview, 14 May,” 2020. 
Most students become more active when online learning takes place. My experience during an online presentation in a course a few days ago was that almost all of my classmates responded with either questions or answers..$^{35}$

Online learning trains students to be more responsible, creative, and independent. Thus, this forms a more confident person. ${ }^{36}$

I have difficulty with internet signals and it consumes a lot of data for online learning. Still, I did not care about the drawbacks because this is the process of becoming a great human being. ${ }^{37}$

All assignments are made easy through an application that helps with online learning. The existence of the COVID-19 pandemic provided wisdom for me as a teacher candidate, so that I would not be too difficult to find a way to teach if there would be another pandemic like this in the future. ${ }^{38}$

\section{Being Financially Efficient}

Besides, another advantage of online learning is that it saves more money than face-toface learning. A concrete example of cost savings is that students can reduce spending money on gasoline for their vehicles, especially when the distance between home and campus is far apart. Students can also save money on room rental fees. Below are the university students' opinions on being financially efficient through online learning.

My motorcycle's gasoline became very efficient because my place of residence to campus was quite far. ${ }^{39}$

Students can save on transportation and housing costs if the university where undergraduate students study is located outside the island or abroad. ${ }^{40}$

\section{Supported Various Learning Media}

Another advantage of implementing the online teaching and learning process is the possibility to use various learning media support. Many students enjoy online learning because it is supported by a variety of learning media, such as YouTube, Google Classroom, Google Meet, PowerPoint, Zoom Application, and WhatsApp. Here is what the students revealed.

My interest to learn grow higher when online learning is conducted via YouTube. For me, listening to an explanation from a teacher is the best method. Furthermore, YouTube makes the experience the same as sitting in a classroom. Moreover, learning through YouTube you learn not only via audio or the voice of the teacher but also through the material described in the video slides. I believe that the more we utilize the five human senses, the more inherent the understanding of the material will be. ${ }^{41}$

I prefer online learning through Google Classroom instead of live Zoom learning because the assignments and deadlines are clear and it does not overload students. ${ }^{42}$

I hope some meetings will use the Google Meet application so that I would be able to greet lecturers and friends. But it does not be every week that we use Google Meet. ${ }^{43}$

\footnotetext{
35 Damaa, "6th-Semester Female University Student, Interview, 9 May," 2020.

${ }^{36}$ Dania, "4th-Semester Female University Student, Interview, 23 May," 2020.

${ }^{37}$ Ramdan, "4th-Semester Male University Student, Interview, 17 May," 2020.

38 Dinara, "6th-Semester Female University Student, Interview, 9 May," 2020.

${ }^{39}$ Almahdi, "6th-Semester Male University Student, Interview, 13 May," 2020.

${ }^{40}$ Sharique, "6th-Semester Male University Student, Interview, 23 May," 2020.

${ }^{41}$ Dinara, "6th-Semester Female University Student, Interview, 9 May."

42 Zhafran, "6th-Semester Male University Student, Interview, 23 May," 2020.
} 
Learning through PowerPoint enables me to be creative as I wish. For example, I can add audio and video to my learning material instead of only writing them. So, the learning is more interesting for me. ${ }^{44}$

Despite I have never used Zoom application before, I think learning to use it is fun and interesting. By using it for classes, I can interact with friends and lecturers to discuss class-related subjects. I So in my opinion Zoom is quite interesting. ${ }^{45}$

I like to choose to use WhatsApp group for discussion because it is accessible to all students and does not require a large internet data. ${ }^{46}$

\section{Weaknesses of Online Learning}

Even though some students found advantages from online learning, some drawbacks were also being identified. These weaknesses are important to serve as an evaluation material that helps to find ways to fill these gaps. Moreover, online learning can last for a longer period since the COVID-19 pandemic is predicted to not only have a short-term impact but as well will have long-term consequences, especially the problem of social inequality. ${ }^{47}$ At least, Universitas Islam Indonesia has attempted to fill the shortage of online learning during the Covid-19 Pandemic, including providing internet connection assistance with 200,000 rupiahs for undergraduate students, ${ }^{48}$ a discount of 700,000 rupiahs from University fees for those affected by Covid-19, ${ }^{49}$ and developing Virtual Private Network (VPN) access by the UII Information Systems Agency to access online learning services and websites such as Zoom, Google Meet, Microsoft Teams, and Google Classroom. ${ }^{50}$ In this study, students stated several shortcomings from the application of online learning during the COVID-19 Pandemic. The main weaknesses are increasing burden from the tasks obtained from the class, declining selfenthusiasm, lacking control from the lecturer, and occurring technical obstacles.

\section{Heavy Tasks}

Self-regulatory abilities and self-efficacy skills can determine success in carrying out the teaching and learning process for students, ${ }^{51}$ however, some students can find it difficult and burdensome in completing online learning. The first shortcoming found in this study is the increased number of assignments received by students compared to the normal teaching and learning process carried out by face-to-face learning. Moreover, the assignments given are quite heavy because lecturers explain less learning materials and students have to learn more independently. This gets even harder because most lecturers give assignments at almost the same time. The following are the students' opinions.

43 Alhaq, "4th-Semester Male University Student, Interview, 9 May,” 2020.

44 Afiya, "6th-Semester Female University Student, Interview, 15 May."

45 Durra, "6th-Semester Female University Student, Interview, 9 May," 2020.

${ }^{46}$ Fadia, "4th-Semester Female University Student, Interview, 9 May,” 2020.

${ }^{47}$ Simon Burgess and Hans Hendrik Sievertsen, "Schools, Skills, and Learning: The Impact of COVID-19 on Education,” VOX CEPR Policy Portal, 2020, https://voxeu.org/article/impact-covid-19-education.

48 Universitas Islam Indonesia, "Bantuan Koneksi Internet Bagi Mahasiswa UII," 2020, https:// fit.uii.ac.id/blog/2020/04/16/bantuan-koneksi-internet-bagi-mahasiswa-uii/.

49 Universitas Islam Indonesia, "Bantuan Untuk Mahasiswa Terdampak Covid-19," 2020, https://www.uii.ac.id/bantuan-untuk-mahasiswa-terdampak-covid-19/.

50 Universitas Islam Indonesia, "Kuota Internet Gratis Untuk Pembelajaran Daring Dan Kerja Dari Rumah,” 2020, https://www.uii.ac.id/kuota-internet-gratis-untuk-pembelajaran-daring-dan-kerja-dari-rumah/.

${ }^{51}$ Rachel L Bradley, Blaine L Browne, and Heather M Kelley, "Examining the Influence of Self-Efficacy and Self-Regulation in Online Learning,” College Student Journal 51, no. 4 (2017): 518-30. 
The disadvantage of online learning is that sometimes there are too many assignments for students. This is difficult especially for those living in remote villages with an unreliable internet connection. 52

As far as I am experiencing online learning, the biggest obstacle is that there are numerous numbers of assignments that we have to do. These assignments are burdensome because we need internet access and some of us live in villages without good internet connection, even worse, with no internet signal. Once the students told the problem to the lecturers, nothing has changed. There is no tolerance and we have to do our assignments. ${ }^{53}$

Some lecturers give too many assignments, while I have all subjects using the current learning model. In the end, it is a build-up of tasks..$^{54}$

Some lecturers give only a little explanation of the material if not at all. Then, we were told to do a lot of assignments. No wonder there are many students are complaining. ${ }^{55}$

\section{Less Effective and Decreased Enthusiasm}

Students think that online learning courses are still considered less effective because they are more focused on theory than practice and tend to be monotonous. Moreover, students feel there are obstacles for them to ask for clarification from the lecturers. This finding is consistent with one of the other studies where student learning performance has decreased. ${ }^{56}$ In the end, students are becoming less enthusiastic and tired of undergoing lectures. This result is similar to another study which revealed that with the sudden implementation of online learning in the presence of the COVID-19 pandemic, there is a potential to make students anxious and this needs to be a concern. ${ }^{57}$ The following are what the students said.

In my opinion, online learning is currently not effective because the material obtained is only limited to understanding the theory but not the practice. Therefore, online learning should only be held once or twice a month. We cannot avoid it because of this pandemic. ${ }^{58}$

Online lectures invite fewer active students. ${ }^{59}$

For me, online learning is monotonous. Some lecturers give only lectures via Zoom without including reading references and the explanation is not fully understood. ${ }^{60}$

In terms of understanding learning materials, it is lacking for several subjects especially if online lectures are used to distribute assignments. Students have to find references for the assignment which is not easy due to bad internet access or power outage. Furthermore, the time given to complete the assignment is pretty short. ${ }^{61}$

It is difficult to ask questions directly to lecturer in online learning because we do not meet in person. ${ }^{62}$

${ }^{52}$ Nadhif, "4th-Semester Male University Student, Interview, 10 May."

${ }^{53}$ Faiza, "4th-Semester Female University Student, Interview, 9 May," 2020.

${ }^{54}$ Zaydan, “4th-Semester Male University Student, Interview, 23 May,” 2020.

${ }^{55}$ Faiqa, "4th-Semester Female University Student, Interview, 12 May," 2020.

56 Siming Guo, "Synchronous versus Asynchronous Online Teaching of Physics during the COVID-19 Pandemic," Physics Education 55, no. 6 (2020): 65007.

${ }^{57}$ Bao, "COVID-19 and Online Teaching in Higher Education: A Case Study of Peking University."

${ }^{58}$ Hidayat, "4th-Semester Male University Student, Interview, 9 May," 2020.

${ }^{59}$ Azlan, "8th-Semester Male University Student, Interview, 12 May," 2020.

${ }^{60}$ Ghania, "6th-Semester Female University Student, Interview, 23 May,” 2020.

${ }^{61}$ Dinara, "6th-Semester Female University Student, Interview, 9 May."

62 Almahdi, "6th-Semester Male University Student, Interview, 13 May." 
During online learning, learning activities become less enthusiastic. ${ }^{63}$

During the COVID-19 pandemic, I feel that I am lazy to think about assignments. ${ }^{64}$

\section{Little Control from The Lecturers}

Another reason that online learning has imperfections is that lecturers are less able to ascertain whether students learn or pay attention when online learning takes place. It can be seen that students often do other things when lecturers provide explanations in online learning, even students choose to sleep unnoticed by the lecturer. The following are the opinions of three students.

The disadvantage of online learning is that lecturers cannot see whether students pay attention and understand what is explained by the lecturer. Another weakness is the loss of signals and internet data packages that unfortunately not all students might be able to buy. ${ }^{65}$

Sometimes some lecturers let their students not turn their video cameras on when using Zoom or just show their names. Thus, it is difficult to control, whether the student is listening to the learning process or just depositing the name of attendance. ${ }^{66}$

Online learning is not conducive. I joined an online class using Zoom that was not very conducive because there were students who took online classes but did not take part in the class. They might sleep or do something else. ${ }^{67}$

\section{Technical Problems}

Many students complain about technical problems in online learning. Those difficulties range from getting an internet connection, running out of internet data, and unexpected power outages. These problems are also expressed by research conducted by Holmes and Gardner about the challenges of implementing online learning where the level of availability of learning media and technology can be a barrier to effectiveness in learning. ${ }^{68}$ Nationally, Indonesia is also facing a serious problem to run online learning because there is only $34 \%$ in the availability of computers. ${ }^{69}$ To overcome some of those problems, students have to sacrifice to get internet connection such as by climbing trees, going to the forest and slope of Merapi mountain, and approaching Telkom (one of the internet providers in Indonesia) tower. Below are their statements:

In my opinion, the lack of online learning is because learning is carried out through internet. The internet connection must be stable. Furthermore, it uses quite a lot of internet quota because most students do not have Wi-Fi.70

Using online learning has many weaknesses, especially those living in villages where signals are difficult and quotas must be purchased while parents' finances are difficult. ${ }^{71}$

\footnotetext{
${ }^{63}$ Ghafira, "4th-Semester Female University Student, Interview, 18 May,” 2020.

${ }^{64}$ Ghalia, "6th-Semester Female University Student, Interview, 11 May," 2020.

${ }^{65}$ Faiza, "4th-Semester Female University Student, Interview, 9 May."

${ }^{66}$ Afiya, "6th-Semester Female University Student, Interview, 15 May."

${ }^{67}$ Damaa, "6th-Semester Female University Student, Interview, 9 May."

${ }^{68}$ Holmes and Gardner, E-Learning: Concepts and Practice.

${ }^{69} \mathrm{Li}$ and Lalani, "The COVID-19 Pandemic Has Changed Education Forever. This Is How."

70 Durra, "6th-Semester Female University Student, Interview, 9 May."

${ }^{71}$ Athafariz, "6th-Semester Male University Student, Interview, 9 May," 2020.
} 
There was once a problem due to a power outage in my place for two days. I was able to attend the classes, but I was late in submitting my assignments due to the problem. ${ }^{72}$

Not all students have and can access the required equipment such as internet quota, Wi-Fi, computers, and laptops for online learning. ${ }^{73}$

The biggest obstacle for me is that it is difficult for me to send assignments because I have to move to find an internet network. Sometimes I climb a tree to get a fairly stable network. ${ }^{74}$

The obstacle of using online learning when an exam is taking place is the sudden loss of network. Sending messages is difficult especially for browsing. So, I had to go to a forest to get an internet network. ${ }^{75}$

My problem is it is difficult to get internet signal. I have to go looking for Telkom tower to get internet signal if I want to upload large files. ${ }^{76}$

I am confused when learning using Zoom because it means I have to find internet connection.

Sometimes I attend class in the middle of a rice field because the signal is pretty good there. Even then, I had to go down because my house was on the slopes of Merapi Mount. ${ }^{77}$

It is too much to buy internet quota. I spend more money from my parents on online learning. I think that is my main obstacle to have online classes. ${ }^{78}$

\section{Constructive Feedbacks on The Implementation of Online Learning}

Even though the availability of online learning media applications currently has more choices and varies compared to previous years and technological development is becoming more rapid, ${ }^{79}$ the implementation of online learning still needs improvement especially during the Covid-19 Pandemic, ${ }^{80}$ including the implementation of online learning at Universitas Islam Indonesia. The Ministry of Education and Culture of the Republic of Indonesia has committed to providing funds of 7.2 trillion rupiah for internet data quota assistance in facilitating information accessibility for teachers, students and lecturers in implementing online learning during the Covid-19 pandemic. $^{81}$ This research provides some feedbacks expressed by undergraduate students in to make online learning work better. The feedbacks are the making of interesting learning videos, fun learning strategies, quizzes, lecture notifications to be multiplied, giving free internet quota. Undergraduate students also hope to be given extra time to submit assignments to avoid stress and maintain their immunity during the Covid-19 pandemic. However, these inputs also need to be followed by the availability of an adequate internet where students living in rural areas in Indonesia still find problems in

72 Radeya, “6th-Semester Male University Student, Interview, 9 May,” 2020.

${ }^{73}$ Ghaisa, "6th-Semester Female University Student, Interview, 23 May,” 2020.

74 Abil, "8th-Semester Male University Student, Interview, 23 May," 2020.

75 Shidqi, “4th-Semester Male University Student, Interview, 23 May,” 2020.

76 Zaydan, "4th-Semester Male University Student, Interview, 23 May."

77 Ghazia, “4th-Semester Female University Student, Interview, 23 May,” 2020.

78 Arsalaan, "4th-Semester Male University Student, Interview, 31 May," 2020.

${ }^{79}$ J Lynn McBrien, Rui Cheng, and Phyllis Jones, "Virtual Spaces: Employing a Synchronous Online Classroom to Facilitate Student Engagement in Online Learning," International Review of Research in Open and Distributed Learning 10, no. 3 (2009).

80 Shivangi Dhawan, "Online Learning: A Panacea in the Time of COVID-19 Crisis," Journal of Educational Technology Systems 49, no. 1 (2020): 5-22, https://doi.org/10.1177/0047239520934018.

81 Kemdikbud RI, "Kemendikbud Resmikan Kebijakan Bantuan Kuota Data Internet 2020," 2020 , https://www.kemdikbud.go.id/main/blog/2020/09/kemendikbud-resmikan-kebijakan-bantuan-kuota-datainternet-2020. 
accessing the internet. ${ }^{82}$ The following are students' perspectives on how to improve the quality of online learning implementation during the Covid-19 pandemic.

Lecturers are expected to provide learning materials in the form of videos so that students can turn on the video over and over to get a better understanding. ${ }^{83}$

I hope that lecturers can find fun learning strategies so that I can learn without feeling bored and dizzy. ${ }^{84}$

Students are provided with quizzes as a conclusion. By these quizzes, students can work to practice and train understanding from the materials given. ${ }^{85}$

My advice for online learning is to provide more notifications to remind students about the tasks. ${ }^{86}$

My hope and suggestion are that for this online learning process, the university or government can provide free internet quotas..$^{87}$

My suggestion is that if lecturers give assignments, give plenty of time for students to complete them. By this, students have less stress and pressure so that they do not need to worry about decreasing immunity. 88

In general, the findings of this research on one hand obtained from interviews with 36 students are very valuable where the researcher divides them into three discussions; advantages of online learning, weaknesses of online learning, and constructive feedback on the implementation of online learning during the Covid-19 pandemic. On the other hand, the findings in this study are not ideal in many perspectives because the data is only obtained from students at one university, and does not involve perspectives of lecturers or policymakers.

\section{CONCLUSION}

The findings of this study broadly consist of three themes as answers to the research questions. Firstly, the advantages of utilizing online learning during the Covid-19 pandemic are that online learning makes students and lecturers increase their technological literacy and flexibility in the learning-teaching process. University students can study and accomplish assignments anywhere and anytime. The application of online learning also improves their abilities in terms of independence, activity, creativity, and responsibility. The students also feel they save more money because they do not need to buy gasoline to travel to campus (reduced transportation cost). Additionally, online learning could be supported by various learning media such as YouTube, Google Classroom, Google Meet, PowerPoint, Zoom Application, and WhatsApp.

Secondly, the implementation of online learning during the Covid-19 pandemic brings weaknesses such as adding students' heavy workload, lack of effectiveness, and decreasing

${ }^{82}$ Djoko Rahardjo, Djuara P Lubis, and İr Sri HARIJATI, "Internet Access and Usage in Improving Student's Self-Directed Learning in Indonesia Open University," Turkish Online Journal of Distance Education 17, no. 2 (2016).

${ }^{83}$ Hadiya, “4th-Semester Female University Student, Interview, 10 May,” 2020.

${ }^{84}$ Dalilah, "4th-Semester Female University Student, Interview, 14 May."

85 Bushra, "4th-Semester Female University Student, Interview, 9 May."

86 Zaydan, "4th-Semester Male University Student, Interview, 23 May."

87 Durra, "6th-Semester Female University Student, Interview, 9 May."

${ }^{88}$ Fahima, "4th-Semester Female University Student, Interview, 11 May," 2020. 
enthusiasm due to lack of understanding of the subjects. University students also find it difficulties to ask questions and clarification to their lecturers, boredom, little control from lecturers in which students join lecturing class while doing other things, and technical problems such as running out of quota, internet connection, and power outage.

Thirdly, the next findings of this study contain student responses or expectations regarding the application of online learning during the Covid-19 pandemic. Students expect that the implementation of online learning will be better through providing interesting learning-teaching videos, fun learning strategies to stop boredom and a drop in enthusiasm for learning, quizzes as self-evaluation material, and more lecture notifications to remind assignments. Students also hope to get a free internet quota from universities or the Indonesian government. Furthermore, they also think of the importance of getting additional time to complete assignments so that undergraduate students who have problems with internet signals or power outages can still complete them according to the given time.

The findings of this study are very comprehensive and can complement some of the previous studies in the implementation of online learning in universities during the Covid-19 pandemic. The researcher thinks that the findings can become a basis for policymakers in universities and the Indonesian government in carrying out online learning. These are also to support the effectiveness of facilities for the use of online learning applications such as the Google Classroom, Panopto, and Zoom obtained by lecturers from the University. Therefore, universities can better carry out online learning where undergraduate students can feel more satisfied with the teaching and learning process by applying the feedback from this research. However, further research related to the implementation of online learning from the perspective of lecturers and policymakers needs to be done to strengthen the findings of this study in the future. Other research is also expected to be carried out in several universities because this research is conducted only at Universitas Islam Indonesia which has a small and specific context.

\section{REFERENCES}

Abil. "8th-Semester Male University Student, Interview, 23 May," 2020.

Afira. "6th-Semester Female University Student, Interview, 10 May," 2020.

Afiya. "6th-Semester Female University Student, Interview, 15 May," 2020.

Aiza. "6th-Semester Female University Student, Interview, 9 May," 2020.

Alhaq. "4th-Semester Male University Student, Interview, 9 May," 2020.

Allen, I Elaine, and Jeff Seaman. Learning on Demand: Online Education in the United States, 2009. ERIC, 2010.

Allo, Markus Deli Girik. "Is the Online Learning Good in the Midst of Covid-19 Pandemic?

The Case of EFL Learners." Jurnal Sinestesia 10, no. 1 (2020): 1-10.

Almahdi. "6th-Semester Male University Student, Interview, 13 May," 2020.

Aqmar. "6th-Semester Male University Student, Interview, 9 May," 2020.

Arsalaan. "4th-Semester Male University Student, Interview, 31 May," 2020.

Athafariz. "6th-Semester Male University Student, Interview, 9 May," 2020.

Azlan. "8th-Semester Male University Student, Interview, 12 May," 2020.

Bai, Yan, Lingsheng Yao, Tao Wei, Fei Tian, Dong-Yan Jin, Lijuan Chen, and Meiyun Wang.

"Presumed Asymptomatic Carrier Transmission of COVID-19." Jama 323, no. 14 
(2020): 1406-7.

Bao, Wei. "COVID-19 and Online Teaching in Higher Education: A Case Study of Peking

University." Human Behavior and Emerging Technologies 2, no. 2 (2020): 113-15.

Barika. "4th-Semester Female University Student, Interview, 9 May," 2020.

Bashirah. "4th-Semester Female University Student, Interview, 9 May,” 2020.

Bowen, José Antonio. Teaching Naked: How Moving Technology out of Your College Classroom Will Improve Student Learning. John Wiley \& Sons, 2012.

Bowers, James, and Poonam Kumar. "Students' Perceptions of Teaching and Social Presence:

A Comparative Analysis of Face-to-Face and Online Learning Environments." International Journal of Web-Based Learning and Teaching Technologies (IJWLTT) 10, no. 1 (2015): 27-44.

Bradley, Rachel L, Blaine L Browne, and Heather M Kelley. "Examining the Influence of SelfEfficacy and Self-Regulation in Online Learning." College Student Journal 51, no. 4 (2017): 518-30.

Burgess, Simon, and Hans Hendrik Sievertsen. "Schools, Skills, and Learning: The Impact of COVID-19 on Education.” VOX CEPR Policy Portal, 2020. https://voxeu.org/article/impact-covid-19-education.

Bushra. "4th-Semester Female University Student, Interview, 9 May," 2020.

Crawford, Joseph, Kerryn Butler-Henderson, Jürgen Rudolph, and Matthias Glowatz. “COVID-19: 20 Countries' Higher Education Intra-Period Digital Pedagogy Responses." Journal of Applied Teaching and Learning (JALT) 3, no. 1 (2020).

Dahlstrom-Hakki, Ibrahim, Zachary Alstad, and Manju Banerjee. "Comparing Synchronous and Asynchronous Online Discussions for Students with Disabilities: The Impact of Social Presence." Computers \& Education 150 (2020): 103842.

Dalilah. "4th-Semester Female University Student, Interview, 14 May,” 2020.

Damaa. "6th-Semester Female University Student, Interview, 9 May," 2020.

Dania. "4th-Semester Female University Student, Interview, 23 May," 2020.

Dhawan, Shivangi. "Online Learning: A Panacea in the Time of COVID-19 Crisis." Journal of Educational Technology Systems 49, no. 1 (2020): 5-22. https://doi.org/10.1177/0047239520934018.

Dinara. "6th-Semester Female University Student, Interview, 9 May," 2020.

Durra. "6th-Semester Female University Student, Interview, 9 May," 2020.

Fadia. "4th-Semester Female University Student, Interview, 9 May," 2020.

Fahima. "4th-Semester Female University Student, Interview, 11 May," 2020.

Faiqa. "4th-Semester Female University Student, Interview, 12 May," 2020.

Faiza. "4th-Semester Female University Student, Interview, 9 May," 2020.

Gazan, Mehmet. "Synchronous and Asynchronous Online Learning: Perceptions of Students at a State University in Turkey." FIRE: Futuristic Implementations of Research in Education 1, no. 2 (2020): 96-107.

Ghafira. "4th-Semester Female University Student, Interview, 18 May," 2020.

Ghaisa. "6th-Semester Female University Student, Interview, 23 May," 2020.

Ghalia. "6th-Semester Female University Student, Interview, 11 May," 2020.

Ghania. "6th-Semester Female University Student, Interview, 23 May,” 2020. 
Ghazia. "4th-Semester Female University Student, Interview, 23 May,” 2020.

Guo, Siming. "Synchronous versus Asynchronous Online Teaching of Physics during the COVID-19 Pandemic." Physics Education 55, no. 6 (2020): 65007.

Hadiya. "4th-Semester Female University Student, Interview, 10 May," 2020.

Hidayat. "4th-Semester Male University Student, Interview, 9 May," 2020.

Holmes, Bryn, and John Gardner. E-Learning: Concepts and Practice. Sage, 2006.

Huberman, A Michael, Mathew Miles, and Johnny Saldana. "Qualitative Data Analysis: A Methods Sourcebook." The United States of America: SAGE Publications, 2014.

Kemdikbud RI. "Kemendikbud Resmikan Kebijakan Bantuan Kuota Data Internet 2020," 2020. https://www.kemdikbud.go.id/main/blog/2020/09/kemendikbud-resmikankebijakan-bantuan-kuota-data-internet-2020.

_. "Panduan Penyelenggaraan Pembelajaran Semester Gasal 2020/2021 Di Perguruan Tinggi." Jakarta, 2020. https://dikti.kemdikbud.go.id/wpcontent/uploads/2020/06/Panduan-Penyelenggaraan-Semester-Gasal-2020-2021-diPT.pdf.

Kemenristekdikti, Pusdatin. "Statistik Pendidikan Tinggi 2018." Jakarta: Pusdatin Iptek Dikti, Setjen, Kemenristekdikti, 2018.

Kementerian Pendidikan dan Kebudayaan. "Surat Edaran Menteri Pendidikan Dan Kebudayaan Republik Indonesia Nomor 36962,” 2020.

Lederman, Doug. "Preparing for a Fall Without In-Person Classes." Inside Higher Ed, 2020. https://www.insidehighered.com/digital-learning/article/2020/04/01/preparingquietly-fall-semester-without-person-instruction.

Li, Cathy, and Farah Lalani. "The COVID-19 Pandemic Has Changed Education Forever. This Is How." World Economic Forum, 2020. https://www.weforum.org/agenda/2020/04/coronavirus-education-global-covid19online-digital-learning/.

McBrien, J Lynn, Rui Cheng, and Phyllis Jones. "Virtual Spaces: Employing a Synchronous Online Classroom to Facilitate Student Engagement in Online Learning." International Review of Research in Open and Distributed Learning 10, no. 3 (2009).

Murphy, Michael P A. "COVID-19 and Emergency ELearning: Consequences of the Securitization of Higher Education for Post-Pandemic Pedagogy." Contemporary Security Policy, 2020, 1-14.

Nadhif. “4th-Semester Male University Student, Interview, 10 May,” 2020.

Radeya. "6th-Semester Male University Student, Interview, 9 May," 2020.

Rahardjo, Djoko, Djuara P Lubis, and İr Sri HARIJATI. "Internet Access and Usage in Improving Student's Self-Directed Learning in Indonesia Open University." Turkish Online Journal of Distance Education 17, no. 2 (2016).

Ramdan. "4th-Semester Male University Student, Interview, 17 May," 2020.

Sharique. "6th-Semester Male University Student, Interview, 23 May," 2020.

Shidqi. “4th-Semester Male University Student, Interview, 23 May,” 2020.

Tchoubar, Tatiana, Thomas R Sexton, and Lori L Scarlatos. "Role of Digital Fluency and Spatial Ability in Student Experience of Online Learning Environments." In Science and Information Conference, 251-64. Springer, 2018. 
The New York Times. "Coronavirus Live Updates: The Number of Cases Is Growing Faster Than Ever Worldwide.” The New York Times, 2020.

UNESCO. "Education: From Disruption to Recovery," 2020. https://en.unesco.org/covid19/educationresponse.

Universitas Islam Indonesia. "Bantuan Koneksi Internet Bagi Mahasiswa UII," 2020. https:// fit.uii.ac.id/blog/2020/04/16/bantuan-koneksi-internet-bagi-mahasiswa-uii/.

-. "Bantuan Untuk Mahasiswa Terdampak Covid-19," 2020. https://www.uii.ac.id/bantuan-untuk-mahasiswa-terdampak-covid-19/.

_. "Kuota Internet Gratis Untuk Pembelajaran Daring Dan Kerja Dari Rumah," 2020. https://www.uii.ac.id/kuota-internet-gratis-untuk-pembelajaran-daring-dan-kerja-darirumah/.

—. "Panduan Perkuliahan Daring Universitas Islam Indonesia." Yogyakarta, 2020. https://docs.google.com/document/u/1/d/e/2PACX-

1vQpfkxDJ8q50jWupY1qzvWcx88VkmX82nPvJDPHC5EvIUFRZiUX1ziQTdfvhho45MGAUr2E1YrsjNG/pub.

Zaydan. "4th-Semester Male University Student, Interview, 23 May," 2020.

Zhafran. "6th-Semester Male University Student, Interview, 23 May,” 2020. 